\title{
HTLV-1/2 is rare among Eastern-European intravenous drug users (IDUs)
}

\author{
Ene-Ly Jõgeda ${ }^{1 *}$, Radko Avi ${ }^{1}$, Merit Pauskar ${ }^{1}$, Eveli Kallas ${ }^{1}$, Tõnis Karki ${ }^{1}$, Don Des Jarlais ${ }^{3}$, Anneli Uusküla², \\ Irja Lutsar ${ }^{1}$, Kristi Huik \\ From 17th International Conference on Human Retroviruses: HTLV and Related Viruses \\ Trois llets, Martinique. 18-21 June 2015
}

\section{Background}

HTLV-1/2 and HIV likely share the same transmission routes and thus in Europe HTLV occurs mainly among IDUs, interests in clinical implications of HTLV-1/2 coinfection on HIV disease progression have risen. So far the available evidence suggests a protective role of HTLV-2 and adverse effect of HTLV-1 on HIV infection. In Europe, the overall prevalence of HTLV infection is up to $18 \%$ among IDUs and less than $1 \%$ among blood donors. However, there is no data regarding the overall prevalence of HTLV-1/2 in Eastern-European IDU population where the HIV epidemic mainly lies. We aimed to determine the prevalence of HTLV among IDUs in Estonia and compare it with the rate in healthy volunteers.

\section{Methods}

The study included 345 Caucasian IDUs and 145 healthy volunteers from Estonia. The presence of HTLV-1/2 was determined by nested PCR in 5' longterminal repeat region; positive controls were used in every PCR run.

\section{Results}

The analysed IDUs resembled IDUs of HIV epidemic in Estonia: the IDU population was mainly male (79\%) with median age of 30 years (interquartile range [IQR] 25-34), and had prolonged duration of illegal drug usage (11 years; IQR=7-14). The rate of co-infections was high - $50 \%$ were $\mathrm{HIV}+, 88 \%$ hepatitis C positive, $67 \%$ hepatitis B positive. $64 \%$ of IDUs reported receptive needle sharing in the past and $18 \%$ at least once a month during last six months. None of the IDUs carried HTLV-1

\footnotetext{
* Correspondence: ene-ly.jogeda@ut.ee

${ }^{1}$ Department of Microbiology, University of Tartu, Tartu, Estonia

Full list of author information is available at the end of the article
}

but there was a case of HTLV-2 (prevalence $0.3 \%$; 95\% CI $0.05-0.0162$ ). Healthy volunteers were HTLV-1 and HTLV-2 PCR negative.

\section{Conclusion}

This is the first study investigating the prevalence of HTLV-1/2 among high risk population and healthy volunteers in Estonia. Our results suggest that HTLV is a rare co-infection among IDUs in Estonia.

\section{Authors' details}

'Department of Microbiology, University of Tartu, Tartu, Estonia. ${ }^{2}$ Department of Public Health, University of Tartu, Tartu, Estonia. ${ }^{3}$ Beth Israel Medical Centre, New York, USA.

Published: 28 August 2015

doi:10.1186/1742-4690-12-S1-P79

Cite this article as: Jõgeda et al:: HTLV-1/2 is rare among EasternEuropean intravenous drug users (IDUs). Retrovirology 2015 12(Suppl 1): P79.
Submit your next manuscript to BioMed Central and take full advantage of:

- Convenient online submission

- Thorough peer review

- No space constraints or color figure charges

- Immediate publication on acceptance

- Inclusion in PubMed, CAS, Scopus and Google Scholar

- Research which is freely available for redistribution

Submit your manuscript at www.biomedcentral.com/submit
C Biomed Central 